GSA Data Repository 2019094

\title{
Tipping the balance: Shifts in sediment production in an active rift setting Pechlivanidou et al.
}

\section{Model input}

The input parameters used for our reference run in pyBadlands in order to model the evolution of the Corinth Rift are summarized in Table DR1.

Table DR1. Reference model input parameters

\begin{tabular}{|c|c|}
\hline \multicolumn{2}{|l|}{ General parameters } \\
\hline Simulation time $[\mathrm{yr}]$ & 130000 \\
\hline Grid cell size $[\mathrm{m}]$ & 100 \\
\hline Boundary conditions & Open boundaries \\
\hline \multicolumn{2}{|l|}{ Forcing parameters } \\
\hline Sea-level & $\begin{array}{l}\text { Sea-level varies through time according to Collier et } \\
\text { al., 2000; Waelbroeck et al., } 2002 \text {. }\end{array}$ \\
\hline Uplift/subsidence evolution & $\begin{array}{l}\text { Cumulative vertical displacement over simulation } \\
\text { time (see Fig. DR1) }\end{array}$ \\
\hline Climate evolution & $\begin{array}{l}\text { Spatial variation in present-day mean precipitation } \\
\text { (data from } \quad \text { www.worldclim.org) } \\
\text { considered } \\
\text { representative over } 130 \mathrm{k} . \mathrm{y} .\end{array}$ \\
\hline \multicolumn{2}{|l|}{ Overland flow parameters } \\
\hline Flow law & $\begin{array}{l}\text { Stream power law given by: } \\
\qquad E=K_{b} A^{\mathrm{m}} S^{\mathrm{n}} \\
\text { where } E \text {, is the incision rate, } A \text { is the upstream } \\
\text { drainage area, } S \text {, is the slope, } K_{\mathrm{b}} \text { is the erodibility } \\
\text { coefficient and } \mathrm{m}, \mathrm{n} \text { are positive empirical } \\
\text { coefficients. } \\
\text { The model is also allowed to deposit sediment } \\
\text { offshore or in depressions following Planchon \& } \\
\text { Darboux (2002). }\end{array}$ \\
\hline $\mathrm{m} / \mathrm{n}$ & 0.5 \\
\hline Erodibility coefficient, $K_{\mathrm{b}}\left[\mathrm{m}^{(1-2 \mathrm{~m})} \mathrm{yr}^{-1}\right]$ & $\begin{array}{l}\text { High erodibility: } 4 \times 10^{-6} \text {; Intermediate erodibility: } \\
2.5 \times 10^{-6} \text {; Low erodibility: } 1.5 \times 10^{-6} \text {. Spatial } \\
\text { variations in } K_{\mathrm{b}} \text { (see erodibility map Fig. DR2) }\end{array}$ \\
\hline \multicolumn{2}{|l|}{ Diffusion parameters } \\
\hline $\begin{array}{l}\text { Marine diffusion coefficient }\left[\mathrm{m}^{2} \mathrm{yr}^{-1}\right] \\
\text { calibrated using offshore isopachs (see } \\
\text { main text) }\end{array}$ & 0.05 \\
\hline $\begin{array}{l}\text { Hillslope diffusion coefficient }\left[\mathrm{m}^{2} \mathrm{yr}^{-1}\right] \\
\text { calibrated using geomorphic analysis (see } \\
\text { below) }\end{array}$ & 0.1 \\
\hline
\end{tabular}

\section{Vertical displacement map}

We compute a 3D continuous vertical surface displacement for the Corinth Rift (Fig. DR1) using a linear elastic dislocation model in Coulomb 3.4 (Toda et al., 2005; Lin \& Stein, 2004). In this model, the vertical surface displacement is calculated using linear elasticity laws for a half-space assumption (Okada, 1992). Total displacement along the fault planes is controlled by the displacement-length scaling factor $(\gamma)$, the fault dip angle and the fault root 
depth (strike-slip component is negligible). We use surface fault traces and cumulative fault slip over 130 k.y. (derived from published slip rates) along the major north-dipping faults to infer a value of 0.04 for the scaling factor $\gamma$. We impose a dip angle of $70^{\circ}$ for the modeled faults in order to match the long-term uplift/subsidence ratio of the major normal faults in the area of $1: 1.2$ to 1 : 2.2 (e.g., Bell et al., 2017) and a fault root depth of $30 \mathrm{~km}$ to best represent the width and flexural geometry of the active Corinth half-graben and the flexural shape of uplifted terraces (e.g., Armijo et al., 1996). The resulting vertical displacement map is divided by $130 \mathrm{k} . \mathrm{y}$. to obtain uplift/subsidence rates and then is validated using constraints on Quaternary fault slip rates along the southern rift margin (see Table DR2). According to Stefatos et al., (2002) the northern margin is under regional subsidence produced by the faults along the southern margin. [Note that both the dip angle and the root depth $\left(70^{\circ}\right.$ and $\left.30 \mathrm{~km}\right)$ used in our study were chosen purely to allow us to fit the observed flexural wavelength given the simplifications inherent in a linear elastic half-space model; Bell et al. (2017) consider a wider variety of rheological models and conclude that high angle faults $\left(45-60^{\circ}\right)$ are most consistent with the field observations.]

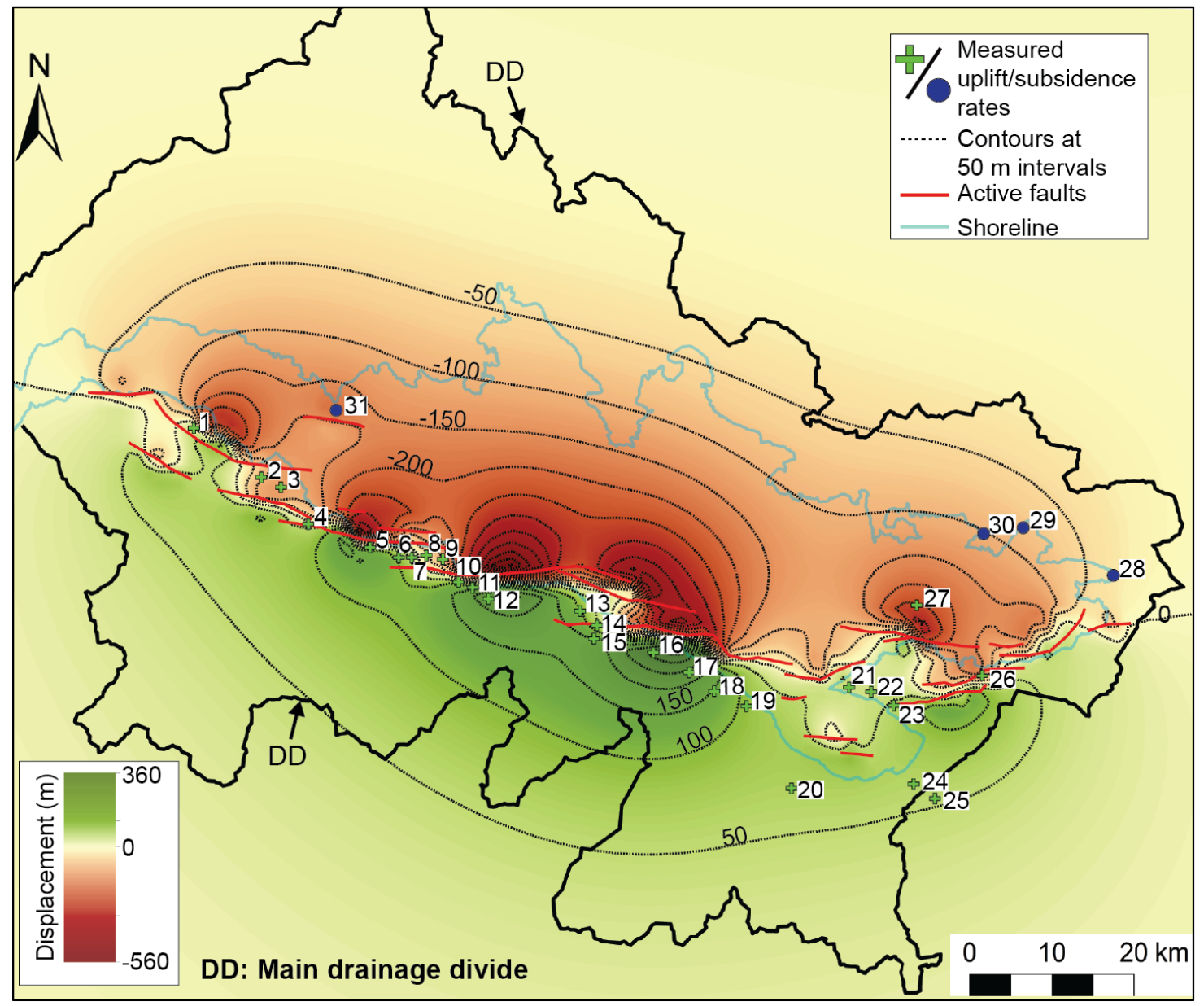

Figure DR1. Vertical displacement map for the Corinth Rift generated using Coulomb 3.4. The contours are cumulative displacement over $130 \mathrm{k} . \mathrm{y}$. The localities where there are measured uplift/subsidence rates (see Table DR2) are shown with green crosses and blue dots, respectively, and are indexed from 1 - 31 . 
Table DR2. Quaternary uplift/subsidence rates that used to validate the vertical displacement map (see Fig. DR1).

\begin{tabular}{|c|c|c|}
\hline & $\begin{array}{c}\text { Published uplift (+) } \\
\text { /subsidence (-) rates } \\
(\mathbf{m m} / \mathbf{y r})\end{array}$ & References \\
\hline 1 & $(+) 0.70-1.0$ & Houghton et al. (2003) \\
\hline 2 & $(+) 1.05-1.20$ & De Martini et al. (2004) \\
\hline 3 & $(+) \sim 1.10$ & De Martini et al. (2004) \\
\hline 4 & $\sim(+) 1.25$ & De Martini et al. (2004) \\
\hline 5 & $(+) 1.0-2.0$ & McNeill \& Collier (2004) \\
\hline 6 & $(+) 0.90-1.50$ & Stewart \& Vita-Finzi (1996) \\
\hline 7 & $(+) 0.80-2.10$ & Stewart (1996) \\
\hline 8 & $(+) 1.40-2.0$ & McNeill \& Collier (2004) \\
\hline 9 & $(+) 1.0-1.6$ & De Martini et al. (2004) \\
\hline 10 & $(+) 1.30-2.20$ & $\begin{array}{c}\text { Stewart \& Vita-Finzi (1996); Stewart (1996); } \\
\text { Pirazzoli et al. (2004) }\end{array}$ \\
\hline 11 & $(+) 1.30-2.20$ & Pirazzoli et al. (2004) \\
\hline 12 & $\sim(+) 1.0$ & Rohais et al. (2007) \\
\hline 13 & $\sim(+) 1.60$ & Bell R. (2008) \\
\hline 14 & $(+) 1.60-1.90$ & Palyvos et al. (2008) \\
\hline 15 & $\sim(+) 1.50$ & Flotté et al. (2005) \\
\hline 16 & $\sim(+) 1.60$ & Collier et al. (1992) \\
\hline 17 & $\sim(+) 1.50$ & Keraudren \& Sorel (1987) \\
\hline 18 & $\sim(+) 1.30$ & Armijo et al. (1996) \\
\hline 19 & $\sim(+) 0.50$ & Morhange et al. (2012) \\
\hline 20 & $\sim(+) 0.44$ & Collier et al. (1992) \\
\hline 21 & $\sim(+) 0.50$ & Leeder et al. (2003) \\
\hline 22 & $(+) 0.20-0.35$ & Leeder et al. (2003) \\
\hline 23 & $\sim(+) 0.30$ & Dia et al. (1997) \\
\hline 24 & $\sim(+) 0.20$ & Dia et al. (1997) \\
\hline 25 & $(+) 0.20-0.30$ & Collier et al. (1992) \\
\hline 26 & $\sim(+) 0.30$ & Leeder et al. (1991) \\
\hline 27 & $\sim(+) 0.30$ & Collier et al. (1992) \\
\hline 28 & $(-) 0.68$ & Vita-Finzi and King (1985); Bell et al. (2009) \\
\hline 29 & $(-) 0.50-0.60$ & Bell R. (2008) \\
\hline 30 & $(-) 0.83$ & Vita-Finzi and King (1985); Bell et al. (2009) \\
\hline 31 & $(-) 0.70-1.0$ & Lykousis et al. (2007) \\
\hline
\end{tabular}

Bedrock erodibility map

Bedrock erodibility map (Fig. DR2B) is generated using the lithostratigraphic units mapped across the Corinth Rift (Kranis, H., 2016; Skourtsos et al., 2016). The observed lithologies are clustered based on elevation and slope (Fig. DR2A) and used to classify bedrock erodibility into three groups; highly erodible deposits with $\left.K_{\mathrm{b}}=4 \times 10^{-6} \mathrm{~m}^{(1-2} \mathrm{m}\right) \mathrm{yr}^{-1}$, intermediate erodible deposits with $K_{\mathrm{b}}=2.5 \times 10^{-6} \mathrm{~m}^{(1-2 \mathrm{~m})} \mathrm{yr}^{-1}$ and low erodible deposits with $K_{\mathrm{b}}=1.5 \times 10^{-6} \mathrm{~m}^{(1-2 \mathrm{~m})} \mathrm{yr}^{-1}$. Fracture density of the bedrock has been neglected in the erodibility classification. The inferred $K_{\mathrm{b}}$ values are calibrated by comparing the modeled and estimated sediment volumes from the interpretation of seismic reflection data (see below). Comparable $K_{\mathrm{b}}$ values in the order of $\left.10^{-5}-10^{-6} \mathrm{~m}^{(1-2} \mathrm{m}\right) \mathrm{yr}^{-1}$ have been inferred from settings composed of similar lithologies (e.g., from the Sperchios basin, Pechlivanidou et al., 2018). We further test the sensitivity of the model for a range of $K_{\mathrm{b}}$ values (see Table DR3). 


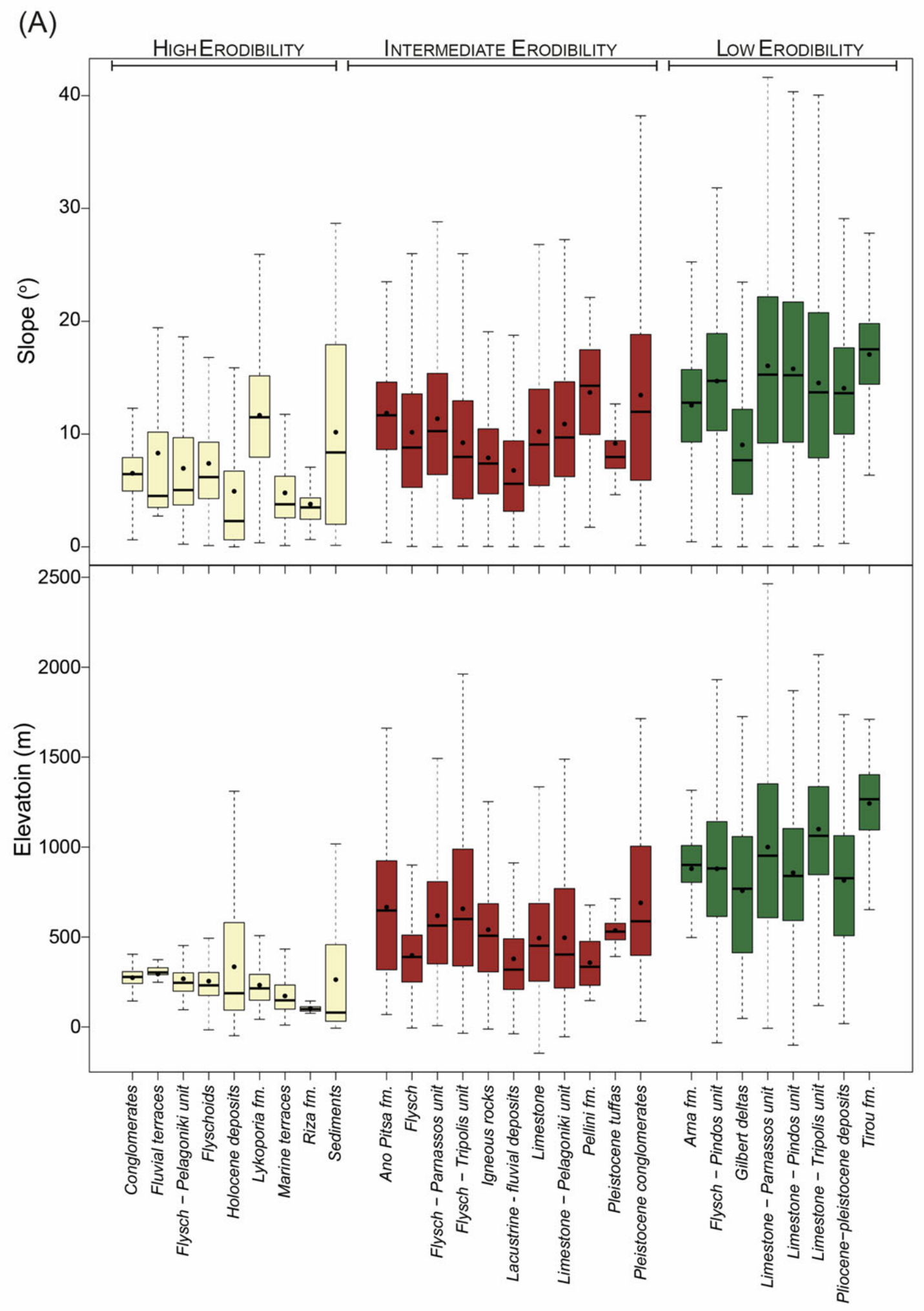

Figure DR2(A), see caption overleaf. 


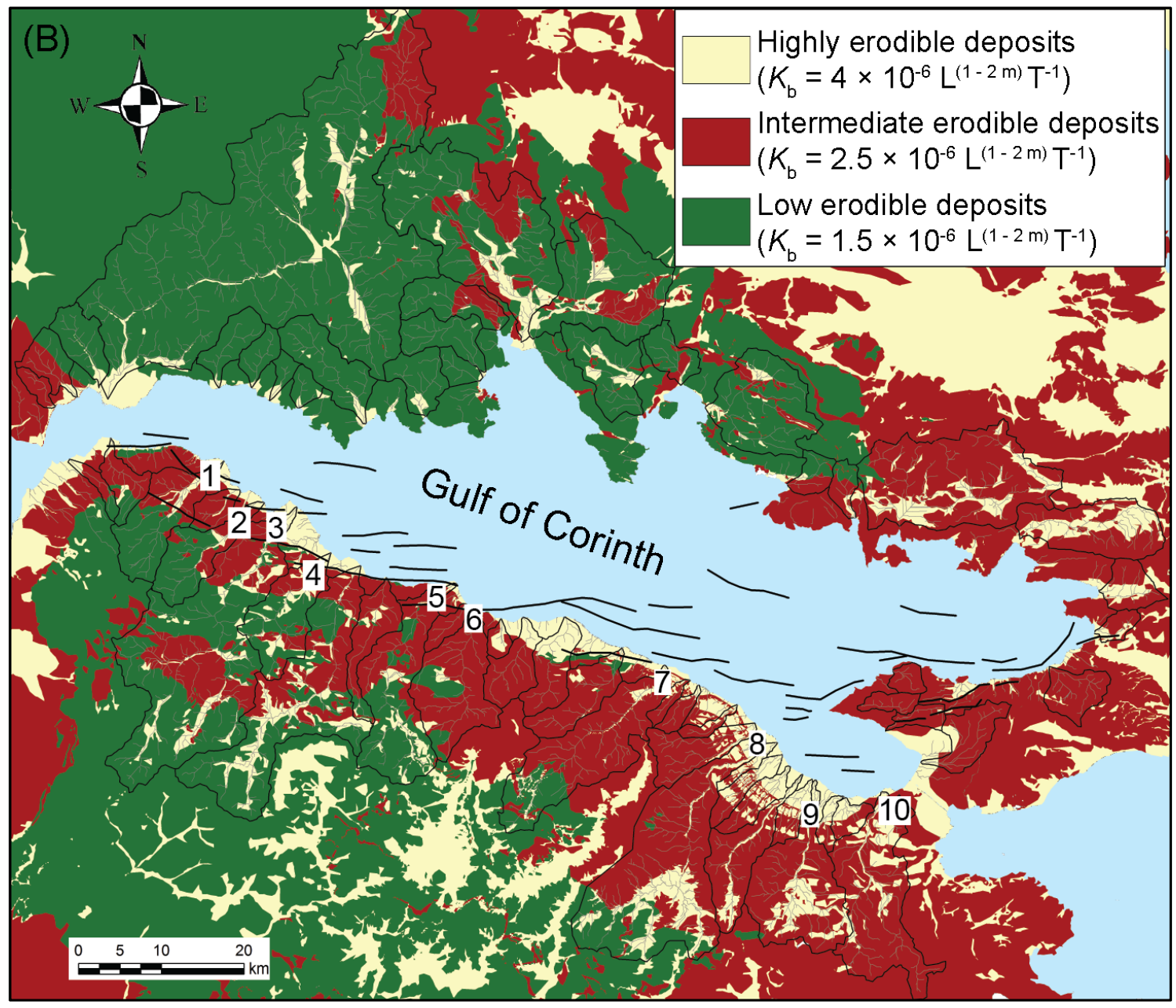

Figure DR2. (A) Distribution of the mapped lithologies according to slope and elevation and (B) bedrock erodibility $\left(K_{\mathrm{b}}\right)$ map of the Corinth Rift. In $(\mathrm{A})$, each box extends between $25 \%$ and $75 \%$ of the data. The black dots show the mean values for each box and the thick black lines show the median values for each box. In (B), numbers from 1 to 10 indicate selected catchments used for model calibration (see Geomorphic analysis).

\section{Model calibration}

\section{Offshore sediment volumes from seismic reflection data}

A linear velocity model of $1.55+1.5 \Delta \mathrm{T}$ was used for the syn-rift sediments and applied to calculate thicknesses and depths of Basement and the two major Seismic Units (see SU1 \& SU2; Nixon et al., 2016). This is based on an array of existing velocity data including Tomography (Zelt et al., 2004) PSDM, (Clement, 2000), Semblance Plots (Bell et al., 2008), Geophysical Core Logs (Collier et al., 2000; Moretti et al., 2004). The velocity model increases the velocity of the syn-rift sediments linearly by $1.5 \mathrm{~km} / \mathrm{sec} / \mathrm{sec}$ from the sea bed surface where the velocity of the sediments has been measured as $1.55 \mathrm{~km} / \mathrm{sec}$ by geophysical core logging (Moretti et al., 2004). This matches a velocity model for calcareous sediments by Hamilton (1985). The sediments were then decompacted using a porosity-depth relationship for calcareous sediments (Goldhammer, 1997).

The estimated offshore volume (i.e., $136 \mathrm{~km}^{3}$ ) was then corrected for data gaps close to the coastline and to the west of Aigion (location on Fig. 1) where no reflection seismic is 
available. The correction was done by extrapolating the 130 k.y. surface (Nixon et al., 2016) to a zero value at the coast, which indicated that an additional $\sim 25 \mathrm{~km}^{3}$ of sediment was deposited in the nearshore area. Our estimate of the sediment volume to the west of Aigion was cross-checked against our model output, which indicated $\sim 8 \%$ of the total volume deposited lies in this area of the rift. We thus estimated a total offshore volume $174.7 \mathrm{~km}^{3}$ for the last $130 \mathrm{k} . y$., from which we calculated a grain volume of $80.4 \mathrm{~km}^{3}$ by removing the pore space (54\% in situ porosity), following Collier et al. (2000).

Furthermore, we calculated a weighted average onshore porosity of $\sim 33 \%$ using the spatial extent of the three main lithologies (see Fig. DR2) and taking into account their relative erodibilities as well. The porosities used (low erodible deposits $8 \%$; intermediate erodible deposits 35\%; high erodible deposits 54\%) are representative porosities from the literature (e.g., Manger et al., 1963). The weighted average onshore porosity is given by:

$$
\sum_{i=1}^{i=3} \frac{K_{\mathrm{bi}}}{\overline{K_{\mathrm{b}}}}\left(A_{i} \varphi_{i}\right)
$$

where $K_{\mathrm{bi}}$ is erodibility of lithology group, $i, A_{i}$ is the fraction of the total drainage area comprised of lithology group, $i, \varphi_{i}$ is the porosity of lithology group, $i$, and $\overline{K_{\mathrm{b}}}$ is the weighted average erodibility (weighted by area $A_{i}$ ). There are three main lithology groups so $i=1$ to 3 .

The weighted average onshore porosity thus obtained was then used to estimate the total onshore (i.e., erosional) volume that would generate an equivalent grain volume (i.e., $\sim 80$ $\mathrm{km}^{3}$ ) as that calculated from the offshore data. We estimated a total of $\sim 120 \mathrm{~km}^{3}$ of onshore volume over the last 130 k.y. (i.e., $9.2 \times 10^{5} \mathrm{~m}^{3} / \mathrm{yr}$ ) that we used to calibrate the surface process model. The relatively wide range of published porosity values contributes some uncertainty, hence why our model calibration also involved geomorphic analysis and sensitivity tests (see below).

Chemical weathering of the carbonate bedrock has not been considered in our modeled sediment volumes because the deposited sediments are clastic calcareous sands, silts and clays generated by the fluvial erosion of the surrounding rift margins (Shillington et al., in press). Moreover, carbonates are not the dominant lithologies $(\sim 40 \%)$ and therefore dissolution presumably has a minor effect on controlling denudation rates. We also note that our modeled sediment flux values (Fig. 1) are comparable to empirical estimates (Watkins et al., 2018).

\section{Geomorphic analysis}

We compared the modelled topography with the results from the morphometric analysis of Demoulin et al. (2015) for selected river catchments to verify that our surface process model and model parameters do not modify the statistical characteristics of the real landscape. In particular, we calculated the hypsometric integral, HI, and the extent of upstream incision, $R_{i}$, after 130 k.y. model run time for ten catchments along the southern rift margin (Fig. DR2B). We obtain values of $\mathrm{HI}$ that agree to within $95 \%$ of the values published by Demoulin et al. (2015) for the same catchments. Moreover, we obtain a correlation between $R i$ and catchment area, $A$, which also compares relatively well to that published by Demoulin et al. (2015) given that we only model $130 \mathrm{k} . \mathrm{y}$. of landscape evolution. In Demoulin et al.'s study the incised area as a percentage of the catchment area is $20 \% \pm 11 \%$ (see Fig. 12 in Demoulin et al., 2015), whereas our model results indicate $26 \% \pm 15 \%$ and thus are, with error, consistent. 
We also compared model runs using non-linear and linear hillslope diffusion. Linear diffusion produced a better match to the typically observed maximum slopes $\left(25-35^{\circ}\right)$ and curvature $( \pm 1.0)$ along the southern margin. Non-linear diffusion generally predicted lower maximum slopes, i.e., $20-30^{\circ}$. In any case, similar sediment volumes are generated in both cases and therefore we present only the results for linear hillslope diffusion.

\section{Sensitivity analysis}

To quantify the uncertainty of our modeling results we perform a series of sensitivity tests where we assess the impact of a range of parameters on sediment production for the northern and southern margins of the Corinth Rift (Table DR3). We compare the total eroded sediment volume from the two rift margins (in $\mathrm{km}^{3}$ ) between our reference run and model runs where each time we vary one parameter. Our sensitivity analysis shows that the use of uniform precipitation with an average value of $0.75 \mathrm{~m} / \mathrm{yr}$, reduces only slightly the produced sediment volumes (i.e., 3.5\% and 4.6\% reduction for the northern and southern margin, respectively; see Model 1, Table DR3). Also, the use of non-linear diffusion for hillslope erosion with a critical slope parameter, Sc, of 1.25 (Roering et al., 1999) or the use of a fixed sea-level on the present-day level do not influence the overall sediment volumes produced from the two rift margins see Models 4 and 5, Table DR3). However, the use of uniform erodibility has a significant impact on our modeling results. In particular, the sediment volume produced from the northern margin increases by $\sim 36 \%$ when using a uniform erodibility of $2.5 \times 10^{-6} \mathrm{~m}^{(1-2}$ ${ }^{\mathrm{m})} \mathrm{yr}^{-1}$ and uniform precipitation (i.e., $0.75 \mathrm{~m} / \mathrm{yr}$, see Model 2, Table DR3). This is because the northern margin mainly consists of lower erodible lithologies (see Fig. DR2B) and by using this value for $K_{\mathrm{b}}$, we increase the erodibility along this margin by $>50 \%$. On the contrary, the effect along the southern rift margin is more subtle (i.e., increase in sediment volume by $8 \%$ ), as this margin mainly consists of intermediate erodible lithologies (see Fig. DR2B).

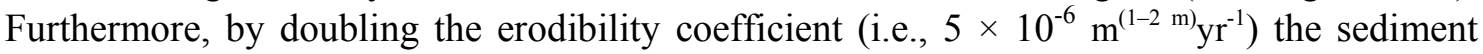
production increases by $186 \%$ and $127 \%$ for the northern and southern margins, respectively (see Model 3, Table DR3).

Table DR3. Sensitivity of modeled sediment volumes (in $\mathrm{km}^{3}$ ) produced from the southern and northern rift margins.

\begin{tabular}{|l|c|c|}
\hline & \multicolumn{2}{|c|}{ Modeled sediment volumes $\left(\mathbf{k m}^{\mathbf{3}}\right)$} \\
\hline Model name & South margin & North margin \\
\hline Reference model & $\mathbf{6 5}$ & $\mathbf{5 8}$ \\
\hline Model 1 (uniform precipitation of $0.75 \mathrm{~m} / \mathrm{yr}$ ) & 62 & 56 \\
\hline $\begin{array}{l}\text { Model } 2 \text { (uniform precipitation of } 0.75 \mathrm{~m} / \mathrm{yr}, \\
\left.\text { uniform erodibility } K_{\mathrm{b}}=2.5 \times 10^{-6} \mathrm{~m}^{(1-2 \mathrm{~m})} \mathrm{yr}^{-1}\right)\end{array}$ & 67 & 76 \\
\hline $\begin{array}{l}\text { Model 3 (uniform precipitation of } 0.75 \mathrm{~m} / \mathrm{yr}, \\
\text { uniform erodibility } K_{\mathrm{b}}=5 \times 10^{-6} \mathrm{~m}^{(1-2 \mathrm{~m})} \mathrm{yr} \mathrm{r}^{-1} \text { ) }\end{array}$ & 141 & 160 \\
\hline $\begin{array}{l}\text { Model } 4 \text { (precipitation map, erodibility map, non- } \\
\text { linear hillslope diffusion with Sc }=1.25 \text { ) }\end{array}$ & 65 & 58 \\
\hline $\begin{array}{l}\text { Model } 5 \text { (uniform precipitation of } 0.75 \mathrm{~m} / \mathrm{yr}, \\
\text { erodibility map, constant sea level at } 0 \mathrm{~m} \text { ) }\end{array}$ & 62 & 56 \\
\hline
\end{tabular}




\section{Analysis of controls on catchment averaged erosion rates}

We analyze the correlation between catchment averaged erosion rate $(\dot{e}, \mathrm{~mm} / \mathrm{yr})$ and maximum catchment relief, $C_{\max }$ (Table DR4) for the catchments along both rift margins: for the southern margin catchments $R^{2}=0.55$; for the northern margin catchments $R^{2}=0.20$. For the southern margin catchments, affected by active faulting, we also analyze the correlation between catchment averaged erosion rate and relative uplift rate at the coastline, $\dot{u}$, (see Fig. DR1) and perform a multiple correlation to understand the combined effect of both $C_{\max }$ and $\dot{u}$. The latter takes into account the correlation between $C_{\max }$ and $\dot{u}\left(R^{2}=0.37\right)$. A somewhat more robust correlation $\left(R^{2}=0.64\right)$ is obtained from the multiple correlation analysis of the southern margin catchments, indicating that both $C_{\max }$ and $\dot{u}$ exert a statistically significant control on catchment averaged erosion rates in these catchments. The multiple regression yields the following result: $\dot{e}=\mathrm{a} C_{\max }+\mathrm{b} \dot{u}+\mathrm{c}$, where $\mathrm{a}=9.73 \times 10^{-5}, \mathrm{~b}=4.76 \times 10^{-2}$ and $\mathrm{c}=5.05 \times 10^{-3}$ (a has the units $\left.\mathrm{yr}^{-1}\right)$. However, the $95 \% \mathrm{CI}$ on parameters a and $\mathrm{b}$ are $\pm 1.5 \times$ $10^{-5}$ and $\pm 2 \times 10^{-2}$ respectively, and $\mathrm{c}$ is not significantly different from zero. Thus, in summary, catchment averaged erosion rate is best described by the relationship: $\dot{e}=$ $1 \times 10^{-4} C_{\text {max }}+5 \times 10^{-2} \dot{u}$ (see main text).

Table DR4. Results of correlation analysis $\left(R^{2}\right.$ coefficients adjusted for sample size). *See Fig. DR3.

\begin{tabular}{|c|c|c|}
\hline & $\begin{array}{c}\text { Southern Margin } \\
R^{2}\end{array}$ & $\begin{array}{c}\text { Northern Margin } \\
R^{2}\end{array}$ \\
\hline$C_{\max }$ & $0.55^{*}$ & 0.2 \\
\hline$\dot{u}$ & $0.32^{*}$ & N/A \\
\hline$C_{\max }$ and $\dot{u}$ & 0.64 & N/A \\
\hline
\end{tabular}
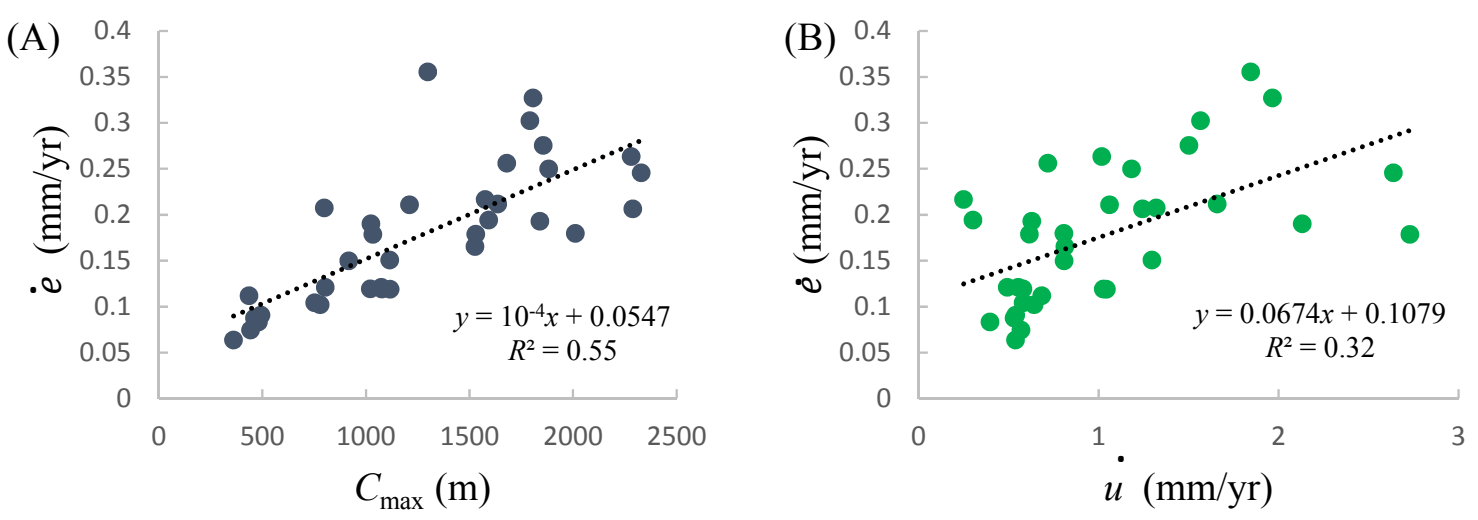

Figure DR3. Catchment averaged erosion rates, $\dot{e}(\mathrm{~mm} / \mathrm{yr})$ versus (A) maximum catchment relief, $C_{\max }(\mathrm{m})$ and (B) uplift rates, $\dot{u}(\mathrm{~mm} / \mathrm{yr})$, for the catchments along the southern Corinth rift margin.

\section{References cited}


Armijo, R., Meyer, B., King, G. C. P., Rigo, A., and Papanastassiou, D., 1996, Quaternary evolution of the Corinth Rift and its implications for the Late Cenozoic evolution of the Aegean: Geophysical Journal International, v. 126, no. 1, p. 11-53, doi:10.1111/j.1365246X.1996.tb05264.X.

Bell, R. E., 2008, Tectonic Evolution of the Corinth Rift, PhD thesis: University of Southampton.

Bell, R. E., McNeill, L. C., Bull, J. M., and Henstock, T. J., 2008, Evolution of the offshore western Gulf of Corinth: Geological Society of America Bulletin, v. 120, p. 156-178, doi:10.1130/b26212.1.

Bell, R. E., McNeill, L. C., Bull, J. M., Henstock, T. J., Collier, R. E. L., and Leeder, M. R., 2009, Fault architecture, basin structure and evolution of the Gulf of Corinth Rift, central Greece: Basin Research, v. 21, p. 824-855, doi:10.1111/j.13652117.2009.00401.x.

Bell, R. E., Duclaux, G., Nixon, C. W., Gawthorpe, R. L., McNeill, L. C., 2017, High-angle, not low-angle, normal faults dominate early rift extension in the Corinth Rift, central Greece. Geology, v 46, no. 2, p. 115-118, doi:10.1130/g39560.1.

Clement, C., 2000, Imagerie sismique crustale de la subduction Hellenique et du Golfe de Corinth, PhD thesis: Univ. Paris VII.

Collier, R. E. L., Leeder, M. R., Rowe, P. J., and Atkinson, T. C., 1992, Rates of Tectonic Uplift in the Corinth and Megara Basins, Central Greece: Tectonics, v. 11, no. 6, p. 1159-1167, doi:10.1029/92tc01565.

Collier, R. E. L., Leeder, M. R., Trout, M., Ferentinos, G., Lyberis, E., and Papatheodorou, G., 2000, High sediment yields and cool, wet winters: Test of last glacial paleoclimates in the northern Mediterranean: Geology, v. 28, no. 11, p. 999-1002, doi:0.1130/00917613(2000)28<999:HSYACW>2.0.CO;2

De Martini, P. M., Pantosti, D., Palyvos, N., Lemeille, F., McNeill, L., and Collier, R., 2004, Slip rates of the Aigion and Eliki Faults from uplifted marine terraces, Corinth Gulf, Greece: Comptes Rendus Geoscience, v. 336, no. 4-5, p. 325-334, doi:10.1016/j.crte.2003.12.006.

Demoulin, A., Beckers, A., and Hubert-Ferrari, A., 2015, Patterns of Quaternary uplift of the Corinth rift southern border (N Peloponnese, Greece) revealed by fluvial landscape morphometry: Geomorphology, v. 246, p. doi:10.1016/j.geomorph.2015.05.032.

Dia, A. N., Cohen, A. S., O'Nions, R. K., and Jackson, J. A., 1997, Rates of uplift investigated through ${ }^{230} \mathrm{Th}$ dating in the Gulf of Corinth (Greece): Chemical Geology, v. 138, no. 3-4, p. 171-184, doi:10.1016/s0009-2541(97)00010-7.

Flotté, N., Sorel, D., Müller, C., and Tensi, J., 2005, Along strike changes in the structural evolution over a brittle detachment fault: Example of the Pleistocene Corinth-Patras rift (Greece): Tectonophysics, v. 403, no. 1-4, p. 77-94, doi:10.1016/j.tecto.2005.03.015.

Goldhammer, R. K., 1997, Compaction and Decompaction Algorithms for Sedimentary Carbonates: SEPM Journal of Sedimentary Research, v. Vol. 67, doi:10.1306/d42684e1-2b26-11d7-8648000102c1865d.

Houghton, S. L., 2003, New ${ }^{234} \mathrm{U}_{-}{ }^{230}$ Th coral dates from the western Gulf of Corinth: Implications for extensional tectonics: Geophysical Research Letters, v. 30, no. 19, doi:10.1029/2003g1018112.

Keraudren, B., and Sorel, D., 1987, The Terraces of Corinth (Greece) - a Detailed Record of Eustatic Sea-Level Variations during the Last 500,000 Years: Marine Geology, v. 77, no. 1-2, p. 99-107, doi:10.1016/0025-3227(87)90085-5. 
Kranis, H., 2016, The missing soft link? Evidence for marginal fault interaction at the southern margin of Geraneia mountains, central Greece: Bulletin of the Geological Society of Greece, v. 50, no. 1, p. 65-74, doi:10.12681/bgsg. 11702.

Leeder, M. R., Seger, M. J., and Stark, C. P., 1991, Sedimentation and tectonic geomorphology adjacent to major active and inactive normal faults, southern Greece: Journal of the Geological Society, v. 148, no. 2, p. 331-343, doi: 10.1144/gsjgs.148.2.0331.

Leeder, M. R., McNeill, L. C., Collier, R. E., Portman, C., Rowe, P. J., Andrews, J. E., and Gawthorpe, R. L., 2003, Corinth rift margin uplift: New evidence from Late Quaternary marine shorelines: Geophysical Research Letters, v. 30, no. 12, doi:10.1029/2003g1017382.

Lin, J., and Stein, R. S., 2004, Stress triggering in thrust and subduction earthquakes and stress interaction between the southern San Andreas and nearby thrust and strike-slip faults: Journal of Geophysical Research: Solid Earth, v. 109, no. B2, doi:10.1029/2003jb002607.

Lykousis, V., Sakellariou, D., Moretti, I., and Kaberi, H., 2007, Late Quaternary basin evolution of the Gulf of Corinth: Sequence stratigraphy, sedimentation, fault-slip and subsidence rates: Tectonophysics, v. 440, no. 1-4, p. 29-51, doi:10.1016/j.tecto.2006.11.007.

Manger, G. E., 1963, Porosity and density of sedimentary rocks: Contributions to Geochemistry, Geological Survey Bulletin, v. 1144-E, p. 60.

McNeill, L. C., and Collier, R. E. L., 2004, Uplift and slip rates of the eastern Eliki fault segment, Gulf of Corinth, Greece, inferred from Holocene and Pleistocene terraces: Journal of the Geological Society, v. 161, p. 81-92, doi:10.1144/0016-764903-029.

Moretti, I., Lykousis, V., Sakellariou, D., Reynaud, J.-Y., Benziane, B., and Prinzhoffer, A., 2004, Sedimentation and subsidence rate in the Gulf of Corinth: what we learn from the Marion Dufresne's long-piston coring: Comptes Rendus Geoscience, v. 336, p. 291-299, doi:10.1016/j.crte.2003.11.011.

Morhange, C., Pirazzoli, P. A., Evelpidou, N., and Marriner, N., 2012, Late Holocene Tectonic Uplift and the Silting Up of Lechaion, the Western Harbor of Ancient Corinth, Greece: Geoarchaeology, v. 27, no. 3, p. 278-283, doi:10.1002/gea.21388.

Nixon, C. W., McNeill, L. C., Bull, J. M., Bell, R. E., Gawthorpe, R. L., Henstock, T. J., Christodoulou, D., Ford, M., Taylor, B., Sakellariou, D., Ferentinos, G., Papatheodorou, G., Leeder, M. R., Collier, R. E. LI., Goodliffe, A. M., Sachpazi, M., and Kranis, H., 2016, Rapid spatiotemporal variations in rift structure during development of the Corinth Rift, central Greece: Tectonics, v. 35, no. 5, p. 1225-1248, doi:10.1002/2015tc004026.

Okada, Y., 1992, Internal deformation due to shear and tensile faults in a half-space. Bulletin of the Seismological Society of America, v. 82, no. 2, p. 1018-1040.

Palyvos, N., Lemeille, F., Sorel, D., Pantosti, D., and Pavlopoulos, K., 2008, Geomorphic and biological indicators of paleoseismicity and Holocene uplift rate at a coastal normal fault footwall (western Corinth Gulf, Greece): Geomorphology, v. 96, p. 16-38, doi:10.1016/j.geomorph.2007.07.010.

Pechlivanidou, S., Cowie, P. A., Hannisdal, B., Whittaker, A. C., Gawthorpe, R. L., Pennos, C., and Riiser, O. S., 2018, Source-to-sink analysis in an active extensional setting: Holocene erosion and deposition in the Sperchios rift, central Greece: Basin Research, v. 30, no. 3, p. 522-543, doi:10.1111/bre.12263.

Pirazzoli, P. A., Stiros, S. C., Fontugne, M., and Arnold, M., 2004, Holocene and Quaternary uplift in the central part of the southern coast of the Corinth Gulf (Greece): Marine Geology, v. 212, no. 1-4, p. 35-44, doi:10.1016/j.margeo.2004.09.006. 
Planchon, O., and Darboux, F., 2002, A fast, simple and versatile algorithm to fill the depressions of digital elevation models: Catena, v. 46, no. 2-3, p. 159-176, doi:10.1016/s0341-8162(01)00164-3.

Roering, J. J., Kirchner, J. W., and Dietrich, W. E., 1999, Evidence for nonlinear, diffusive sediment transport on hillslopes and implications for landscape morphology: Water Resources Research, v. 35, no. 3, p. 853-870, doi:10.1029/1998wr900090.

Rohais, S., Eschard, R., Ford, M., Guillocheau, F., and Moretti, I., 2007, Stratigraphic architecture of the Plio-Pleistocene infill of the Corinth Rift: Implications for its structural evolution: Tectonophysics, v. 440, no. 1-4, p. 5-28, doi:10.1016/j.tecto.2006.11.006.

Shillington, D.J., McNeill, L.C., Carter, G., and Expedition 381 Scientists, Expedition 381 Preliminary Report: Corinth Active Rift Development: International Ocean Discovery Program (in press).

Skourtsos, E., Kranis, H., Zambetakis-Lekkas, A., Gawthorpe, R. L., and Leeder, M., 2016, Alpine basement outcrops at northern Peloponnesus: implications for the early stages in the evolution of the Corinth Rift: Bulletin of the Geological Society of Greece, v. 50, no. 1, p. 153-163, doi:10.12681/bgsg.11714.

Stefatos, A., Papatheodorou, G., Ferentinos, G., Leeder, M., and Collier, R., 2002, Seismic reflection imaging of active offshore faults in the Gulf of Corinth: their seismotectonic significance: Basin Research, v. 14, no. 4, p. 487-502, doi:10.1046/j.13652117.2002.00176.x

Stewart, I., 1996, Holocene uplift and palaeoseismicity on the Eliki Fault, Western Gulf of Corinth, Greece: Annals of Geophysics, v. 39, p. 575-588, doi:10.4401/ag-3993.

Stewart, I., and Vita-Finzi, C., 1996, Coastal uplift on active normal faults: The Eliki Fault, Greece: Geophysical Research Letters, v. 23, no. 14, p. 1853-1856, doi:10.1029/96gl01595.

Toda, S., 2005, Forecasting the evolution of seismicity in southern California: Animations built on earthquake stress transfer: Journal of Geophysical Research, v. 110, no. B5, doi:10.1029/2004jb003415.

Vita-Finzi, C., and King, G. C. P., 1985, The Seismicity, Geomorphology and Structural Evolution of the Corinth Area of Greece: Philosophical Transactions of the Royal Society A: Mathematical, Physical and Engineering Sciences, v. 314, no. 1530, p. 379407, doi:10.1098/rsta.1985.0024.

Waelbroeck, C., Labeyrie, L., Michel, E., Duplessy, J. C., McManus, J. F., Lambeck, K., Balbon, E., and Labracherie, M., 2002, Sea-level and deep water temperature changes derived from benthic foraminifera isotopic records: Quaternary Science Reviews, v. 21, no. 1-3, p. 295-305, doi:10.1016/S0277-3791(01)00101-9.

Watkins, S. E., Whittaker, A. C., Bell, R. E., McNeill, L. C., Gawthorpe, R. L., Brooke, S. A. S., and Nixon, C. W., 2018, Are landscapes buffered to high-frequency climate change? A comparison of sediment fluxes and depositional volumes in the Corinth Rift, central Greece, over the past 130 k.y: GSA Bulletin, doi:10.1130/b31953.1.

Zelt, B. C., Taylor, B., Weiss, J. R., Goodliffe, A. M., Sachpazi, M., and Hirn, A., 2004, Streamer tomography velocity models for the Gulf of Corinth and Gulf of Itea, Greece: Geophysical Journal International, v. 159, p. 333-346, doi:10.1111/j.1365246X.2004.02388.x. 